\title{
Histological evaluation and In situ localization of apoptosis in fresh and cryopreserved ovarian tissue
}

\author{
Mohamed A. Bedaiwy, M.D. ${ }^{* \dagger}$ \\ Mahmoud R. Hussein, M.D., Ph.D. ${ }^{\ddagger}$ \\ Departments of Obstetrics and Gynecology, Minimally Invasive Surgery Center, Cleveland Clinic Foundation, Cleveland, Ohio; \\ department of Obstetrics and Gynecology, and Pathology Department, Assiut School of Medicine, Assiut, Egypt.
}

\begin{abstract}
Objective: To study the feasibility of using combined morphology and terminal deoxynucleotidyl transferase-mediated dUTP-digoxigenin nick-end labeling (TUNEL) for apoptosis detection and the impact of cryopreservation on this process.

Materials and methods: We conducted this investigation using a porcine animal model. Bilateral oophorectomy was performed in eight sows. The ovarian tissues were divided into two parts; one part was immediately fixed while the other was cryopreserved. The cryopreserved specimens were subsequently thawed and then fixed. All the specimens were sectioned, fixed and stained with H\&E. The ovarian follicles were counted, histologically categorized as healthy and atretic and evaluated for the presence of apoptosis. Then, in situ examination of apoptosis was performed using TUNEL assay.

Results: In the cryopreserved tissues: 1 ) the count of the primordial follicle was significantly reduced as compared to freshly- fixed samples ( $4.9 \pm 5.3$ vs. $7.2 \pm 5.4, p=0.03$ respectively) and 2) the mean values of apoptosis were insignificantly higher when compared to the freshly-fixed group $(p=0.74)$. Moreover: 1$)$ apoptosis was found in the atretic, but not in the healthy follicles (primordial, primary and secondary); 2) the nuclei of the granulosa cells, but not those of theca or stromal cells, were TUNEL positive; 3 ) some cells with histological features of necrosis and apoptosis were TUNEL negative, and 6) The distribution of apoptosis was not different between cryopreserved tissue and freshly fixed tissue.

Conclusions: the presence of apoptosis in the atretic follicles may suggest its involvement in follicular atresia; and 2) combined histology and TUNEL assay may be a useful method for detection of apoptosis.
\end{abstract}

Key words: Apoptosis/ovarian cryopreservation/Morphology/TUNEL assay.

In 1885, the first observation of apoptosis in the ovary was made following morphological analysis of granulosa cells in the rabbit ovary (1). This form of cell death is involved in the ovarian homeostasis (2) and its regulation depends on a balance between

\footnotetext{
*Department of Obstetrics and Gynecology, Minimally Invasive Surgery Center, Cleveland Clinic Foundation, Cleveland, Ohio 44195

${ }^{\dagger}$ Department of Obstetrics and Gynecology,

${ }^{\ddagger}$ Pathology Department, Assiut School of Medicine, Assiut, Egypt. Presented in part in: 58th Annual Meeting of the American Society for Reproductive Medicine, Oct 12-17, 2002 Seattle Correspondence: Mohamed A. Bedaiwy, MD, Department of Ob. Gyn., Assiut School of Medicine, Assiut, Egypt, Phone: 088364258, Fax: 088-333327, Email: bedaiwymmm@yahoo.com
}

survival factors and apoptotic factors (3, 4). Morphologically, apoptosis is characterized by specific changes, such as cytoplasmic vacuolization, chromatin condensation and formation of apoptotic bodies (5, 6). Biochemically, apoptosis is characterized by DNA fragmentation into oligonucleosome-sized fragments (6). This DNA fragmentation has been examined in the pig ovarian tissues; using DNA fluorescence flowcytometry (7) and autoradiography (8-10). However, these methods have the following limitations 1 ) they require large amounts of DNA and 2) they do not allow identification of apoptotic changes in specific tissue compartments or at the single cell level. 
Although morphology provided the original criteria for apoptosis and therefore remains as a reliable indicator, detection of early apoptotic changes may be beyond the scope of histological examination. Alternatively, it is well known that apoptosis may occur without evidence of DNA fragmentation (11) and therefore its detection becomes beyond the scope of terminal deoxynucleotidyl transferase-mediated dUTPdigoxigenin nick-end labeling (TUNEL) assay. The use of morphology in combination with TUNEL assay to examine apoptosis may produce more clear and unequivocal results (12). However, knowledge about this combined strategy is scarce so far. With the growing interest in ovarian tissue cryopreservation to scavenge the fertility of those at risk, the response of the different ovarian cellular elements to the cryopreservation insults is not well studied. To fill this gap in the literature, we examined apoptosis in porcine ovarian tissues using this combined method. We addressed three questions 1) what are the patterns of apoptosis in the pig ovary? Does it affect healthy follicles?; 2) what are the feasibility and advantages of this method?, and 3) what is the effect of cryopreservation on this process?

\section{MATERIALS AND METHODS}

\section{Tissues}

Bilateral oophorectomy was performed in eight sows at the Cleveland Clinic Foundation Biological Research Unit in accordance with standard operating procedures. Each specimen was divided into two parts; one part was immediately fixed in Bouin solution for histology while the other was cryopreserved according to the protocol by Gosden and his colleagues (13). The cryopreserved tissues were kept in liquid nitrogen for 3 months, and then thawed. Serial 4-6 $\mu \mathrm{m}$ sections were cut from both freshly fixed and cryopreserved tissues, mounted on glass slides and placed in a $60 \mathrm{o} \mathrm{C}$ oven for 30 minutes. The Bouinfixed sections were then deparaffinized in xylene, rehydrated through graded alcohol and stained with hematoxylene and eosin for histological examination.

\section{Histological evaluation of follicular health and atresia}

The follicles were categorized into two groups, healthy and atretic, following the established morphological criteria (14). The healthy follicles were those with intact membrana granulosa and few pyknotic nuclei ( $<5 \%$ pyknotic nuclei) in this layer. Alternatively, atretic follicles showed attenuated membrana granulosa, disruption, loosely attached granulosa cells and increased number of pyknotic nuclei ( $>5 \%$ pyknotic nuclei) (15).

\section{Histological evaluation of apoptosis}

Hematoxylene and eosin sections were examined, and histological evaluation of apoptosis followed the established criteria reported in the original paper by Kerr and his colleagues (16). These criteria include condensed nuclear fragments, nuclei with marginated chromatin, multiple nuclear fragments, a single condensed nucleus, membrane-bound structures containing variable amounts of chromatin and/or cytoplasm and eosinophilic cytoplasm.

\section{TUNEL assay for detection of apoptotic cells}

To evaluate the apoptotic response in the pig ovarian tissue, we applied terminal deoxynucleotidyl transferase (TdT)-mediated dUTP-digoxigenin nick-end labeling (TUNEL assay) technique, to both the cryopreserved and Bouin-fixed sections, using the commercially available QIA33TDT-FragEL ${ }^{\mathrm{TM}}$ kits (Oncogen Research Products, Boston, MA 02118, USA). The Bouin-fixed sections (4-5 $\mu \mathrm{m})$ mounted on glass slides were deparaffinized, rehydrated through graded alcohols to water, treated with $20 \mu \mathrm{g} / \mathrm{ml}$ proteinase $\mathrm{K}$ ( $37^{\circ} \mathrm{C}, 20$ minutes) and then washed in $1 \mathrm{X}$ Tris buffer. TUNEL assay was then performed according to the instructions by the manufacturer. Briefly, endogenous peroxidase activity was blocked with 3\% H202 in methanol. Sections were then rinsed in $1 \mathrm{X}$ Tris buffer and covered with $5 \mathrm{X} \mathrm{TdT}$ equilibration buffer at $37^{\circ} \mathrm{C}$ 
Figure 1. HL 60 cells (Control). Negative controls stained with TUNEL technique failed to show any immunoreactivity, while signal-positive TUNEL staining was observed in the positive controls.

for 30 minutes. The buffer was blotted from the slides, and TdT labeling reaction mixture $(57.0 \mu \mathrm{l}$ TdT labeling solution and $3.0 \mu \mathrm{l}$ TdT enzyme) was added at $370 \mathrm{C}$ for 1.5 hours. The reaction was terminated by rinsing in $1 \mathrm{X}$ Tris buffer and covering the sections with $100 \mu \mathrm{l}$ STOP solution for 5 minutes. Then the sections were incubated with blocking buffer and 50X conjugate solution for 10 and 30 minutes, respectively. The slides were rinsed in $1 \mathrm{X}$ Tris buffer, and the entire specimen was covered with DAB solution for 15 minutes. The nuclei were counterstained with $5 \%$ methyl green, and the sections were treated with $100 \%$ ethanol, cleared in xylene and cover-slipped.

\section{Evaluation of apoptosis (TUNEL assay)}

In accordance with other groups $(17,18)$, the results of the TUNEL assay were evaluated according to the signal intensity as follows -, negative and + , positive.

\section{Positive and negative controls}

Positive controls were obtained from the manufacturer (Oncogen Research Products, Boston, MA 02118, USA) and consisted of formaldehyde-fixed, paraffin-embedded sections from HL60 promyelocytic leukemia cells and HL60 cells incubated with $0.5 \mu \mathrm{g} / \mathrm{ml}$ actinomycin $\mathrm{D}$ for 19 hours to induce apoptosis. Some ovarian tissue specimens were used as negative controls by substituting a microliter of distilled water for the deoxynucleotidyl transferase from the protocol, as suggested by others (19-22). All the sections were then examined with a BH2 Olympus microscope. 
Figure 2. Healthy follicles were TUNEL - negative

\section{Photography}

All photographs were taken using a camera attachment with the Olympus BH2 microscope.

\section{Statistical analysis}

Statistical analysis was done using Analysis of Variance (ANOVA) (Statistix for Windows, 1985, 96 Analytical Software Program). Differences were considered statistically significant at $\mathrm{p}<0.05$.

\section{RESULTS}

\section{Histological evaluation}

When the results between the cryopreserved and freshly- fixed groups were compared: 1) the number of primordial follicles was significantly reduced ( $4.9 \pm 5.3$ vs. $7.2 \pm 5.4, p=0.03)$ and 2$)$ the differences in the percentage of the primary and secondary follicles between the two groups were not significant. Generally, granulosa cells with the histological features of apoptosis were observed in atretic follicles either within the central region of the membrana granulosa layer or loosely attached to the membrana granulosa near its antral surface or in the antral follicular fluid (Figures 1-3).

\section{TUNEL assay}

None of the negative controls stained with TUNEL technique showed any immunoreactivity, while signal-positive TUNEL staining was observed in the positive controls (Figure 1). The evaluation of apoptosis in ovarian tissues revealed several observations. First, the healthy (primordial, 
Figure 3. Atretic follicles; TUNEL-positive signals were detected in the atretic follicles as indicated by the punctuated brown staining of the fragmented nuclei of granulosa cells.

primary and secondary) follicles were TUNELnegative (Figure 2). Second, TUNEL-positive signals were detected in the atretic follicles as indicated by the punctuated brown staining of the fragmented nuclei of granulosa cells (Figure 3). As in histological evaluation, the positively stained nuclei were observed either in the central layers of the membrana granulosa, at the antral surface or floating in the follicular antrium. Apoptosis was absent both in the interstitial cells and in the theca cells of the atretic follicles. Third, although many of the pyknotic nuclei and the DNA globules sloughed in the cavities of the atretic follicles were stained intensely with hematoxylene, they were TUNEL-negative. Forth, although the mean values of apoptotic cells were slightly higher in the cryopreserved tissues as compared to the freshly fixed ones (1.8 vs. 1.8 ; 2.0 vs. $2.0 ; 2.1$ vs. $2.1 ; 2.3$ vs. 2.5 and 2.4 vs. 2.8 at $1,5,10,20$ and 30 minutes respectively), none of these differences were statistically significant. Finally, the localization of apoptosis was not significantly affected by cryopreservation of the ovarian tissue.

\section{DISCUSSION}

Although previous studies have reported apoptotic changes in the pocrine ovarian tissues using several molecular techniques (7-10), these methods require large amounts of DNA and do not allow identification of apoptotic changes in specific tissue compartments or at the single cell level. Alternatively the combined approach proposed by our study has the following advantages 1) it can be performed on conventional histological sections without disruption of their architecture; 2) it allows direct microscopic 
visualization and detection of apoptosis in specific tissue compartments and at the single cell level; and 3) it is a rapid non-radioactive method allowing for the investigation of a large number of cases.

In agreement with previous studies, our results revealed the lack of apoptosis in the healthy follicles (primordial, primary and secondary) when compared to the atretic ones $(18,23-25)$. The absence of apoptotic signals in the healthy follicles following a cryopreservation, thawing and immediate analysis lends further support to the fact that apoptosis is a dynamic process that requires active metabolism and usually takes several hours or even days to be executed (26-29). Moreover, the presence of apoptotic changes in the atretic follicles both extend the previous molecular findings (10) and lend further support to the link between apoptosis and ovarian follicular atresia. This apoptotic response in the atretic follicles may be due to the activation of endonucleases that cleave genomic DNA into oligonucleosomal fragments (30). It is also possible that substances that stimulate apoptosis may have atretogenic effects on the ovarian follicles. Of note, follicular atresia plays a critical role in recruitment of follicles for ovulation as well as in their depletion during menopause and premature ovarian failure (31). Interestingly, although many of the pyknotic nuclei and DNA globules sloughed in the cavities of the atretic follicles showed intense staining with hematoxylene, apoptosis assays revealed that they were TUNEL-negative, and . This discrepancy may be due to the inaccessibility of supercondensed DNA in these cells to the TdT enzyme.

The clinical significance of our study stems from two main factors. First, the critical impact of apoptosis on the outcome of fertilization and oocyte development. In this regard, the inability to conceive is associated with a higher rate of apoptosis in their granulosa-lutein cells (32-34). Second, our study proposes the combined morphology and TUNEL assay as useful and simple strategy for the detection of apoptosis ovarian tissue destined for transplantation.

Apoptosis in the cryopreserved ovarian tissues occurs with a similar localization to fresh tissue. Apoptosis in cryopreserved tissue may also occur because: during cryopreservation process, the ovarian tissues receive apoptosis-triggering signals. With a further freeze-thaw trauma; the primed cells in the cryopreserved tissues were forced to commit suicide by activation-induced apoptosis $(35,36)$. It is also possible that cryopreservation of these tissues was associated with degradation of apoptosis related proteins (caspase-3, caspase-8, Bcl-2 and actin) with subsequent alteration of their function and enhancement of apoptotic activity (37-39). Given the fact that the insignificantly higher apoptosis mean values were observed only in the atretic and not the healthy follicles, it is conceivable that: 1) these changes may reflect preexisting atretic changes or the occasional apoptosis in the endothelial cells and 2) cryopreservation does not seem to be responsible for any further follicular damage provided that the appropriate freeze-thaw protocol is being used.

In summary, our study revealed that 1) apoptotic cell death occurs in the atretic follicles but not in the healthy ones in pig ovary; 2) combined TUNEL assay and histological examination offers a suitable method for detection of apoptosis in the ovarian tissues. It also confirms the notion that apoptosis is central to ovarian atresia. The potential value of this combined method in the clinical setting, such as in the evaluation of the integrity of the tissue for ovarian transplantation, mandates further investigations.

\section{ACKNOWLEDGEMENTS}

We wish to thank Dr T. Falcone MD, E Jeremias MD, A Agarwal.PhD, Department of Obstetrics and Gynecology, The Cleveland Clinic foundation, Cleveland, Ohio, USA for their kind support.

\section{REFERENCES}

1. Tilly JL. Apoptosis and ovarian function. Rev Reprod 1996; 1: $162-72$.

2. Andreu-Vieyra CV and Habibi HR. Factors controlling ovarian apoptosis. Can J Physiol Pharmacol 2000; 78: 1003-12.

3. Guthrie HD, Garrett WM, and Cooper BS. Folliclestimulating hormone and insulin-like growth factor-I attenuate apoptosis in cultured porcine granulosa cells. Biol 
Reprod 1998; 58: 390-6.

4. Rouillier P, Matton P, Dufour M, Sirard MA, Guilbault LA. Steroid production, cell proliferation, and apoptosis in cultured bovine antral and mural granulosa cells: development of an in vitro model to study estradiol production. Mol Reprod Dev 1998; 50: 170-7.

5. Wyllie AH, Kerr JF, and Currie AR. Cell death: the significance of apoptosis. Int Rev Cytol 1980; 68: 251-306.

6. Gold R, Schmied M, Giegerich G, Breitschopf H, Hartung $\mathrm{HP}$, Toyka KV, et al. Differentiation between cellular apoptosis and necrosis by the combined use of in situ tailing and nick translation techniques. Lab Invest 1994; 71: 219-25.

7. Guthrie HD, Cooper BS, Welch GR, Zakaria AD, Johnson LA. Atresia in follicles grown after ovulation in the pig: measurement of increased apoptosis in granulosa cells and reduced follicular fluid estradiol-17 beta. Biol Reprod 1995; 52: 920-7.

8. Tilly JL, Kowalski KI, Johnson AL, et al. Involvement of apoptosis in ovarian follicular atresia and postovulatory regression. Endocrinology 1991; 129: 2799-801.

9. Tilly JL, Kowalski KI, Schomberg DW, et al. Apoptosis in atretic ovarian follicles is associated with selective decreases in messenger ribonucleic acid transcripts for gonadotropin receptors and cytochrome P450 aromatase. Endocrinology 1992; 131: 1670-6.

10. Manabe N, Imai $\mathrm{Y}$, Ohno $\mathrm{H}$, et al. Apoptosis occurs in granulosa cells but not cumulus cells in the atretic antral follicles in pig ovaries. Experientia 1996; 52: 647-51.

11. Zamai L, Falcieri E, Marhefka G, et al. Supravital exposure to propidium iodide identifies apoptotic cells in the absence of nucleosomal DNA fragmentation. Cytometry 1996; 23: 303-11.

12. Gujral JS, Bucci TJ, Farhood A, et al. Mechanism of cell death during warm hepatic ischemia-reperfusion in rats: apoptosis or necrosis? Hepatology 2001; 33: 397-405.

13. Gosden RG, Baird DT, Wade JC, Webb R. Restoration of fertility to oophorectomized sheep by ovarian autografts stored at -196 degrees C. Hum Reprod 1994; 9: 597-603.

14. Wood TC, Montali RJ, and Wildt DE. Follicle-oocyte atresia and temporal taphonomy in cold-stored domestic cat ovaries. Mol Reprod Dev 1997; 46: 190-200.

15. Blondin P, Dufour M, and Sirard MA. Analysis of atresia in bovine follicles using different methods: flow cytometry, enzyme-linked immunosorbent assay, and classic histology. Biol Reprod 1996; 54: 631-7.

16. Kerr JF, Wyllie AH, Currie AR. Apoptosis: a basic biological phenomenon with wide-ranging implications in tissue kinetics. Br J Cancer 1972; 26: 239-57.

17. Li J, Kim JM, Liston P, Mackenzie AE et al. Expression of inhibitor of apoptosis proteins (IAPs) in rat granulosa cells during ovarian follicular development and atresia. Endocrinology 1998; 139: 1321-8.

18. Kim JM, Yoon YD, and Tsang BK. Involvement of the Fas/Fas ligand system in p53-mediated granulosa cell apoptosis during follicular development and atresia. Endocrinology 1999; 140: 2307-17.

19. Gavrieli Y, Sherman Y, and Ben-Sasson SA. Identification of programmed cell death in situ via specific labeling of nuclear DNA fragmentation. J Cell Biol 1992; 119: 493-501.

20. Liu TJ, El-Naggar AK, McDonnell TJ, Steck KD, Wang M, Maylor DL et al. Apoptosis induction mediated by wild-type p53 adenoviral gene transfer in squamous cell carcinoma of the head and neck. Cancer Res 1995; 55: 3117-22.

21. Su JH, Anderson AJ, Cummings BJ, Cotman CW. Immunohistochemical evidence for apoptosis in Alzheimer's disease. Neuroreport 1994; 5: 2529-33.

22. Wijsman JH, Jonker RR, Keijzer R, van de Velde CJ, Cornelisse CJ, van Dierendonck JH. A new method to detect apoptosis in paraffin sections: in situ end- labeling of fragmented DNA. J Histochem Cytochem 1993; 41: 7-12.

23. Billig H, Furuta I, and Hsueh AJ. Gonadotropin-releasing hormone directly induces apoptotic cell death in the rat ovary: biochemical and in situ detection of deoxyribonucleic acid fragmentation in granulosa cells. Endocrinology 1994; 134: 245-52.

24. Palumbo A. and Yeh J. In situ localization of apoptosis in the rat ovary during follicular atresia. Biol Reprod 1994; 51: 888-95.

25. Van Wezel IL, Dharmarajan AM, Lavranos TC, Rodgers RJ. Evidence for alternative pathways of granulosa cell death in healthy and slightly atretic bovine antral follicles. Endocrinology 1999; 140: 2602-12.

26. Scarabelli T, Stephanou A, Rayment N, Pasini E, Comini L, Curello $\mathrm{S}$ et al. Apoptosis of endothelial cells precedes myocyte cell apoptosis in ischemia/reperfusion injury. Circulation 2001; 104: 253-6.

27. Stammberger U, Gaspert A, Hillinger S, Vogt $\mathrm{P}$, et al. Apoptosis induced by ischemia and reperfusion in experimental lung transplantation. Ann Thorac Surg 2000; 69: 1532-6.

28. Stephanou A, Scarabelli TM, Brar BK, Nakanishi Y, Matsumura M, Knight RA et al. Induction of apoptosis and Fas receptor/Fas ligand expression by ischemia/reperfusion in cardiac myocytes requires serine 727 of the STAT-1 transcription factor but not tyrosine 701. J Biol Chem 2001; 276: 28340-7.

29. Stephanou A, Brar B, Liao Z, Scarabelli T. Distinct initiator caspases are required for the induction of apoptosis in cardiac myocytes during ischaemia versus reperfusion injury. Cell Death Differ 2001; 8: 434-5.

30. Wyllie AH. Glucocorticoid-induced thymocyte apoptosis is associated with endogenous endonuclease activation. Nature 1980; 284: 555-6.

31. Gilbert AB, Perry MM, Waddington D, Hardie MA. Role of atresia in establishing the follicular hierarchy in the ovary of the domestic hen (Gallus domesticus). J Reprod Fertil 1983; 69: 221-7.

32. Nakahara K, Saito H, Saito T, Ito M, Ohta N, Takahashi T et al. The incidence of apoptotic bodies in membrana granulosa can predict prognosis of ova from patients participating in in vitro fertilization programs. Fertil Steril 1997; 68: 312-7.

33. Nakahara K, Saito H, Saito T, Ito M, Ohta N, Takahashi T et al. The incidence of apoptotic bodies in membrana granulosa of the patients participating in an in vitro fertilization program. Fertil Steril 1997; 67: 302-8.

34. Oosterhuis GJ, Michgelsen HW, Lambalk CB, Schoemaker J, Vermes I. Apoptotic cell death in human granulosa-lutein cells: a possible indicator of in vitro fertilization outcome. Fertil Steril 1998; 70: 747-9.

35. Yahata T, Abe N, Yahata C, Ohmi Y, Ohta A, Iwakabe K et al. The essential role of phorbol ester-sensitive protein kinase C isoforms in activation-induced cell death of Th1 cells. Eur 
J Immunol 1999; 29: 727-32.

36. Zhu L, Yu X, Akatsuka Y, Cooper JA, Anasetti C. Role of mitogen-activated protein kinases in activation-induced apoptosis of T cells. Immunology 1999; 97: 26-35.

37. Schmidt-Mende J, Hellstrom-Lindberg E, Joseph B, Zhivotovky B. Freezing induces artificial cleavage of apoptosis-related proteins in human bone marrow cells. J Immunol Methods 2000; 245: 91-4.

38. Zhivotovsky B, Burgess DH, Vanags DM, Orrenius S.
Involvement of cellular proteolytic machinery in apoptosis. Biochem Biophys Res Commun 1997; 230: 481-8.

39. Zhivotovsky B, Burgess DH, Schlegel J, Porn MI, Vannags D, Orrenius S. Proteases in Fas-mediated apoptosis. J Cell Biochem 1997; 64: 43-9.

Received on May 9, 2004; revised and accepted on June 8, 2004 


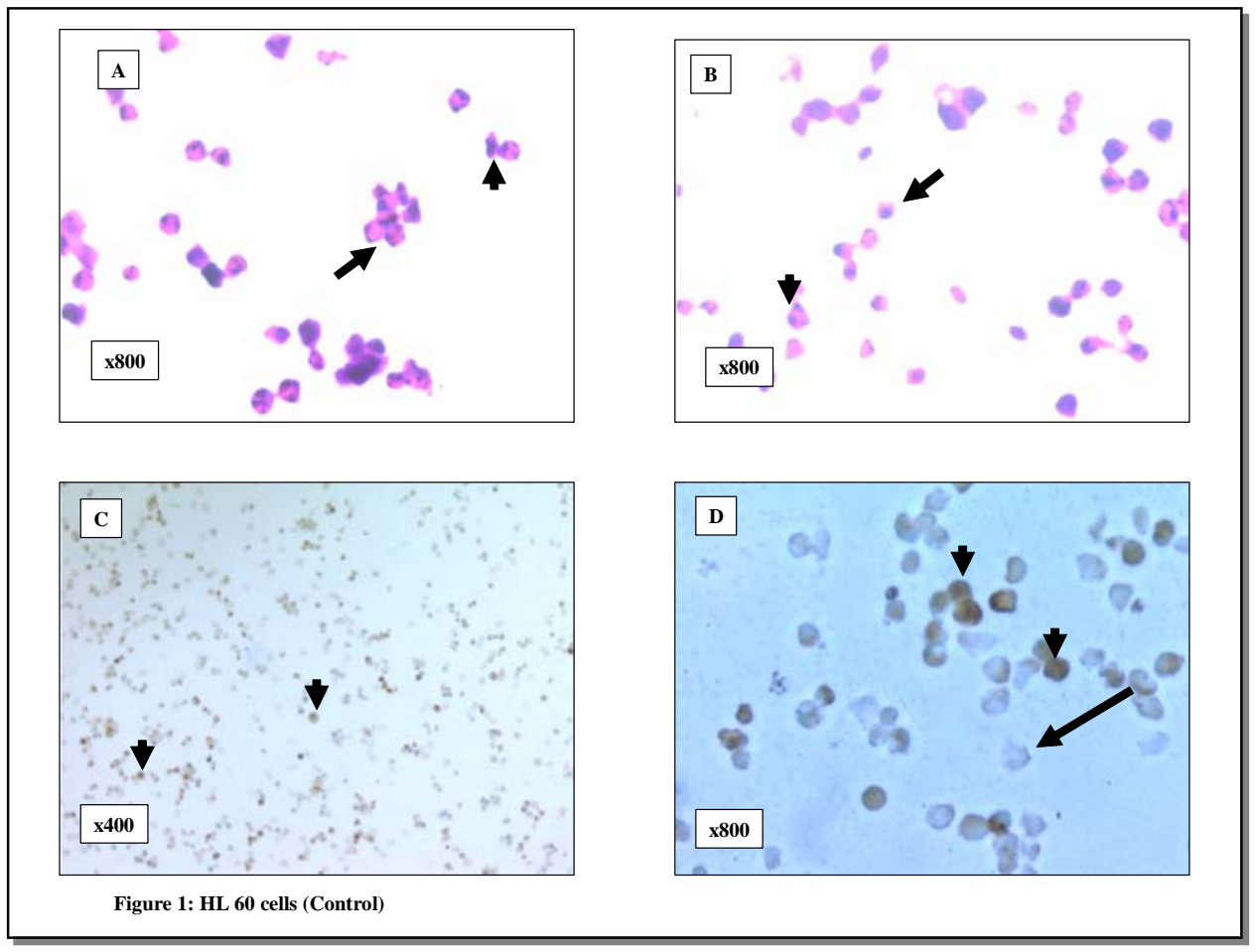



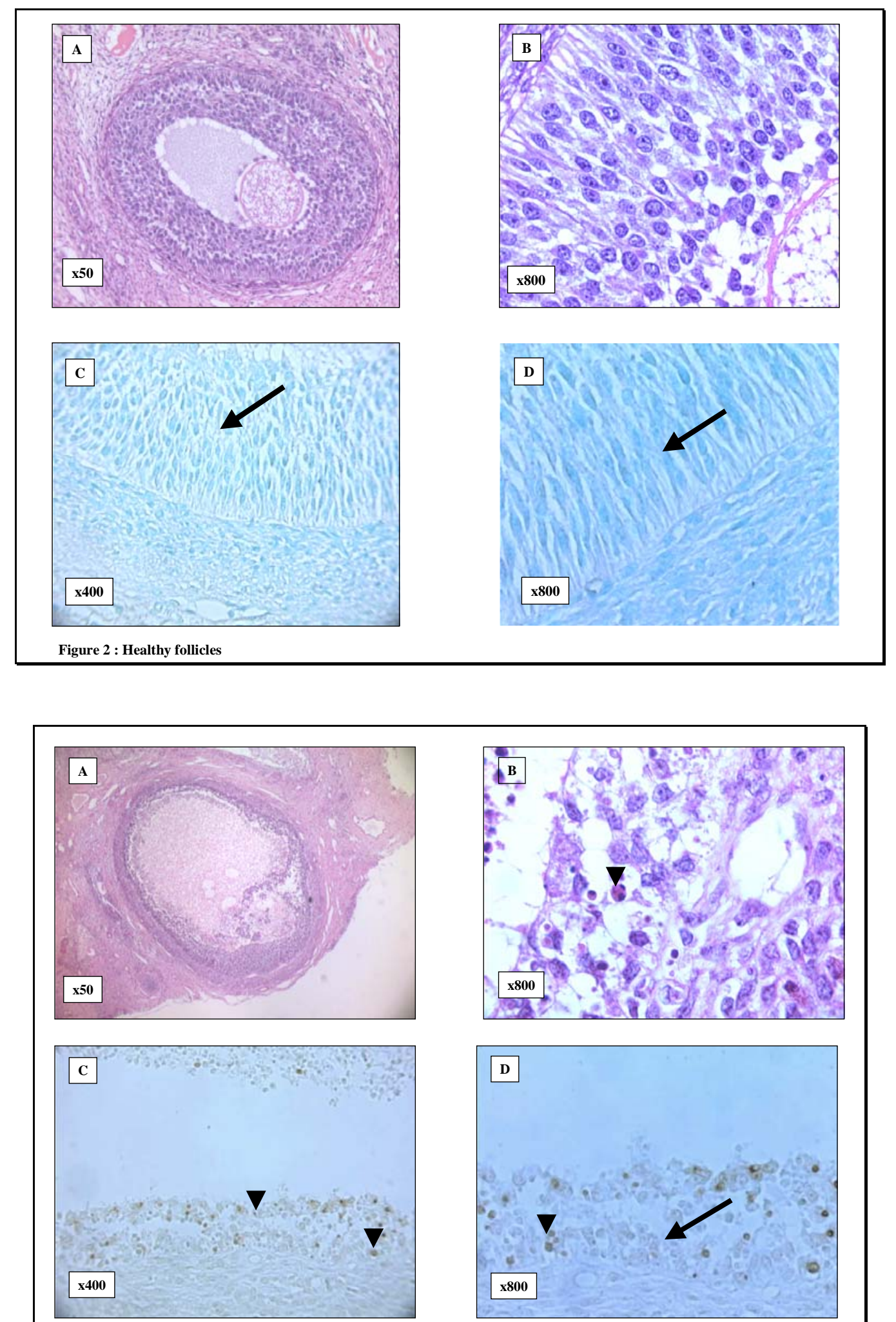

Figure 3: Atretic follicles 